\title{
Known and anticipated medical geology issues in Ghana
}

Raymond Webrah Kazapoe

Department of Geological Sciences, University for Development Studies, Tamale and Pan African University of Life and Earth Sciences Institute (including Health and Agriculture), University of Ibadan, Ibadan, Nigeria

Emmanuel Arhin

Earth Science, C.K. Tedam University of Technology and Applied Sciences, Navrongo, Ghana, and

Ebenezer Ebo Yahans Amuah Environmental Science Department, Kwame Nkrumah University of Science and Technology, Kumasi, Ghana

\section{9}

Received 24 June 2020 Revised 26 November 2020 14 February 2021 Accepted 6 March 2021

\begin{abstract}
Purpose - This paper aims to review the known and anticipated medical geology problems in Ghana, to highlight the impact of some trace elements on human health and to reveal some essential aspects of medical geology on health.
\end{abstract}

Design/methodology/approach - Literature and empirical studies relating to medical geological issues in Ghana were reviewed. Secondary data were used in the present study such as case studies, reports, geological bulletins and published research studies.

Findings - High levels of heavy metals including arsenic, cadmium and mercury in gold extraction processes through artisanal small-scale mining have contributed to high concentrations of toxic elements in the environment. The distribution and availability of these elements in the environment are facilitated by the geological, chemical and local environmental activities that are irregularly spread exposing people mining areas to pollutions. Exposures to these elements in above and below baseline levels contributed to health implications including fluorosis, intellectual or developmental disability and death in some regions of Ghana. Cardiovascular and cerebrovascular diseases linked to mining activities were also presented in this study. Similarly, non-communicable diseases can affect many people if correct measures are not considered. Following the geometric increase in mining activities, it is anticipated that deleterious environmental and health impacts associated with mining may persist in mining areas in Ghana. Reported implications and continuous contamination of water bodies in mining areas could result in high pollution levels beyond treatment for human use or destroy aquatic habitats and aquatic lives through acid drainage. Abovethreshold concentrations of heavy metals in soils could bio-accumulate in crops, and this could pose deleterious public health implications on consumers. Continuous effects posed on the environment and public health may prompt communities, regulatory institutions and government to reduce or ban mineral development.

Originality/value - This review has significantly revealed potential public health issues from the impact on the natural environment and recommends that medical geologists work together with medical

(C) Raymond Webrah Kazapoe, Emmanuel Arhin and Ebenezer Ebo Yahans Amuah. Published in Ecofeminism and Climate Change. Published by Emerald Publishing Limited. This article is published under the Creative Commons Attribution (CC BY 4.0) licence. Anyone may reproduce, distribute, translate and create derivative works of this article (for both commercial and noncommercial purposes), subject to full attribution to the original publication and authors. The full terms of this licence maybe seen at http://creativecommons.org/licences/by/4.0/legalcode

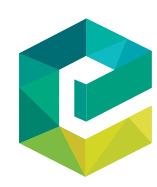

Ecofeminism and Climate Change Vol. 2 No. 4,2021 pp. 169-18 e-ISSN: 2633-4070 e-ISSN: $2633-4070$
p-ISSN: $2633-4062$ DOI 10.1108/EFCC-06-2020-0020 
EFCC 2,4

workers to devise preventive and therapeutic techniques to address many geology-related-health issues in Ghana.

Keywords Environmental health, Toxicity, Geological process, Deficiency, Geological materials, Trace elements

Paper type General review

\section{Introduction}

Many bacterial, viral, fungal and parasitic diseases have gained significant medical attention unlike diseases linked to trace elements in the natural environments (National Research Council, 1989; Singh et al., 2016; Nkinahamira et al., 2019). However, some trace elements have been associated with cardiovascular diseases, hypertension and diabetes. Medical Geology studies have shown health-related complications from elements emanating from geologic materials. Howbeit, Selinus et al. (2005) indicated that less attention has been accorded to the interrelation between geology and health. For instance, some Medical Practitioners have attributed cardiovascular diseases to plaque build-up that thickens and stiffens artery walls that inhibit blood flow through arteries to many organs and tissues in the body (Chen, 2020). Similarly, several studies in medicine including Integris (2017) and WHO (2017a, 2017b) have described the causes of cardiovascular diseases to correctable problems including unhealthy diet, lack of exercise or being overweight and smoking. However, little has been attributed to the sources and debilitating impacts associated with exposure to trace elements in the natural environment.

Interestingly, studies in medical geology have shown that many diseases including cardiovascular diseases are related to elements from weathered rocks after their interactions with water and other agents of weathering. The released elements may be in below- or abovethreshold limits in the natural environment and have the propensity to pose impacts on public health (England and Richardson, 1977; Selinus et al., 2005). Exposures to these elements are primarily through ingestion, inhalation and absorption through dermal contact (De Miguel et al., 2007). The uptake of elements by plants and the dissolution of elements in drinking water have also been shown to have debilitating effects on global public health. Reported health consequences of millions of the vulnerable, particularly women and children in the developing world are likely to relate generally to the consumption of locally produced foods and water with no standard checks of elements contents (Arhin and Kazapoe, 2017; Arhin et al., 2019).

Situating this act of consuming unstandardized foods and water, Kaplan (2016) states that:

We are what we eat and drink. Therefore, medical geology issues if not tackled may devolve into serious public health challenges. This may be more so in Ghana due to the exploitation of precious minerals that inadvertently introduce new harmful elements into the environment and also facilitates the spread of potentially harmful elements (PHE) in the natural environment.

The quality of soils for food cultivation and the regolith that hosts the drinking water has been identified by medical geology research to be closely associated with the quality of health (Arhin et al., 2019). Rocks with different chemical compositions naturally release different elements into the environment. Similarly, variations in soil formation processes coupled with the differences in local environmental activities result in variance in soil geochemistry particularly in the environment where there is an abundance of water and oxygen to facilitate chemical reactions (Singh and Spiccia, 2013; Hunter et al, 2016). This and many other factors reported by many studies including Tack et al. (1997) and Chen et al. (1999) explain the varying concentrations of elements in soils. Following the environmental and health implications associated with geologic material and to avert disease-outbreaks related to these materials, there is the need to: 
- Identify, characterized and mark geographic areas of the natural sources of harmful elements in the environment.

- Develop scientific techniques that predict the transport and alterations of chemicals in the environment.

- Understand the degrees of exposure of elements and pathways to humans.

Case study area

The mining district of South-western Ghana which hosts many known mineral industries including the world-class gold deposit at Obuasi as described by Kesse (1985) was selected for this study. Studies on gold resources in the Birimian of Ghana (Figure 1) have identified chalcophile minerals containing elements such as copper $(\mathrm{Cu})$, zinc $(\mathrm{Zn})$, gallium $(\mathrm{Ga})$, silver $(\mathrm{Ag})$, cadmium (Cd), indium (In), mercury (Hg), titanium (TI), arsenic (As), sulfur (S), antimony (Sb), selenium (Se), lead (Pb), bismuth (Bi) and tellurium (Te) (Kesse, 1985; Dzigbodi-Adjimah, 1993). Medical geology studies have identified some of the listed elements to be potentially harmful whereas others are essential to human well-being. The elements released from rocks may have varying concentration levels. Additionally, these elements may be released into the environment while others will be absorbed by other minerals to form compounds depending on the $\mathrm{pH}$ levels and organic matter. Dispersal traces of the elements and the concentration levels in the surface

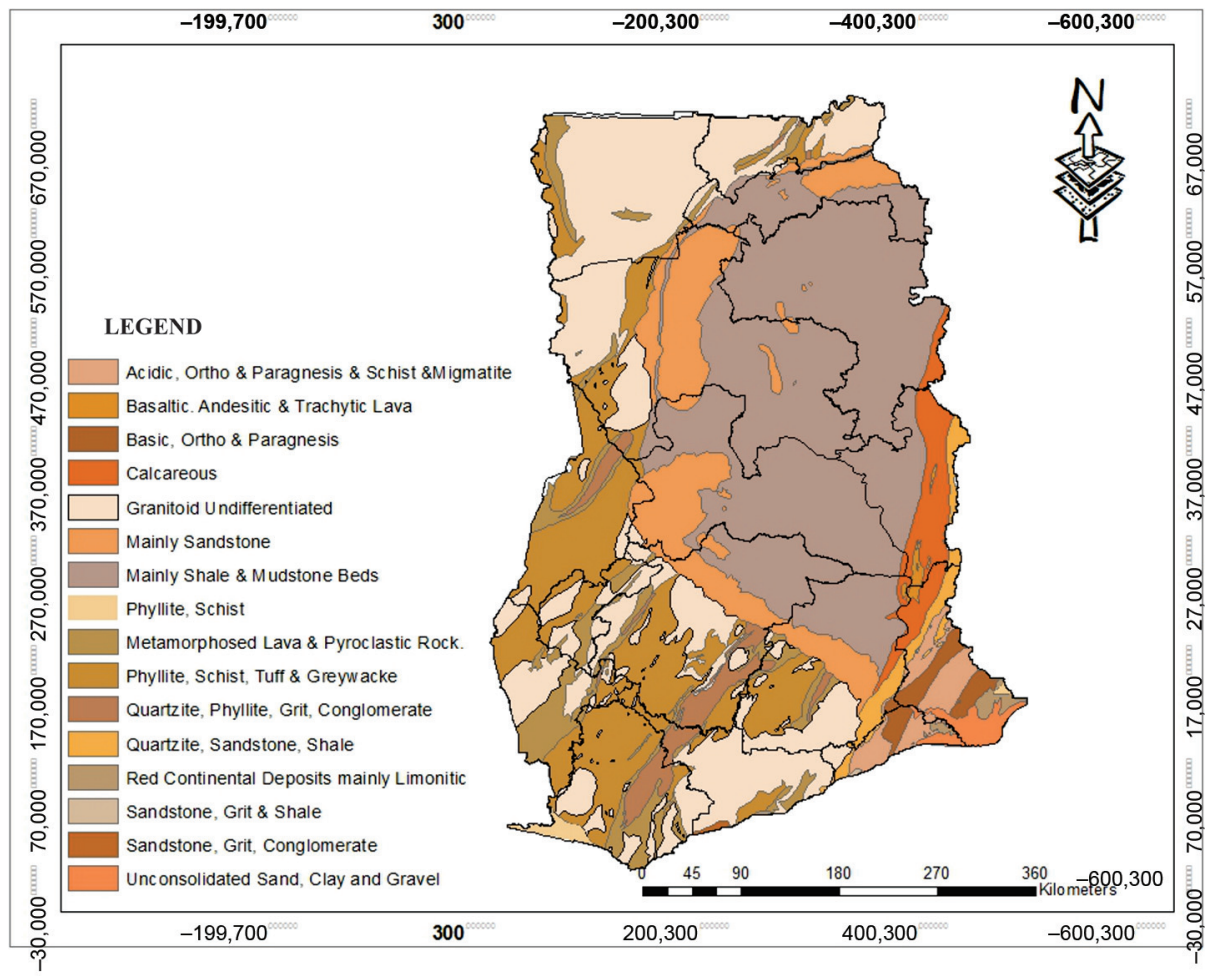

Figure 1. Geological map of Ghana 
EFCC 2,4

Table 1.

Summary statistics of major and trace elements in soil samples in the study area (unit measurements in $\mathrm{mg} / \mathrm{kg})$ environment may differ due to environmental activities and characteristics (Wong et al., 2006). The concern of this review is that multiple accounts of gold resource exploitation have been published adequately in Ghana with correspondingly insufficient information on the linkages between geology, environment and health. Medical geologists have discussed that the impact of elemental exposures highly dependent on the dose of the elements exposed. This implies that element exposure irrespective of element-type may either lead to good or adverse health outcomes (Selinus et al., 2005; Flanagan et al., 2012; Lovell et al., 2014; Arhin et al., 2015). This paper, therefore, presents the known and anticipated medical geology problems, highlights the likely impact of As exposure and the possible health implications in parts of south-west Ghana.

The express need to highlight the known and anticipated medical geology issues is facilitated in parts by a report made by a local news network in Ghana, JoyNews (2017), which documented some medical doctors' suspicion of renal diseases in parts of western and central regions to be linked to the mining activities prevalent in those areas. The hazardous effects caused by excessiveness or deficiency of essential and non-essential trace elements including As, fluoride (F), iodine (I), $\mathrm{Hg}$, Se, radon (Rn), manganese (Mn), $\mathrm{Cd}$ and $\mathrm{Pb}$ demonstrate the good of incorporating medical geology toward the pathway of attaining the internationally-agreed goals $1,2,3$ and 4. It is, therefore, vital for Ghana to survey to create geochemical atlases to outline areas with elemental excesses and deficiencies that pose potential effects on man's health and well-being. The insufficient information on the relationship between the sources of non-communicable diseases and medical geology in developing countries is a major contributing factor to the widespread of generally uncommon diseases in the urban and rural communities in Ghana which are on a rise (Arhin et al., 2020). Arhin et al. (2019) in a study within mining areas in the Western Region of Ghana identified disparities in the average levels of As, Chromium (Cr), Iron (Fe) and Magnesium (Mg) compared to global background averages. The measured averages of As and $\mathrm{Cr}$ was $17.27 \mathrm{mg} / \mathrm{kg}$ and $89.25 \mathrm{mg} / \mathrm{kg}$, respectively, for the entire area. These exceeded the worldwide background values of $10 \mathrm{mg} / \mathrm{kg}$ and $8 \mathrm{mg} / \mathrm{kg}$ of $\mathrm{As}$ and $\mathrm{Cr}$.

Incidentally, in Ghana, sources of disease-causing-elements and their related diseases are inadequately studied. The health consequences emanating from the lack of knowing areas with excesses and deficiencies of disease-causing elements continue to influence disease patterns in different geographic locations. This makes the national achievement of health for all as enshrined in SDG 3 very challenging to achieve. Similarly, non-communicable disease prevention requires crosscollaboration among the scientific community including medical geologists and health workers. As identified by Arhin et al. (2019) in the Wassa Traditional area of Ghana, trace elements such as As, Cobalt (Co), $\mathrm{Cr}, \mathrm{Pb}$ and Nickle (Ni) had minimum and maximum analytical values as shown in the summary statistics presented in Table 1 . The minimum measured values for the trace elements compared to the global acceptable values in soils appeared lower while the maximum measured values far exceeded the global acceptable values. Other studies have also recognized close linkages

\begin{tabular}{|c|c|c|c|c|c|c|c|c|c|c|}
\hline & $\begin{array}{l}\text { As } \\
10\end{array}$ & $\begin{array}{c}\mathrm{Ba} \\
430\end{array}$ & $\begin{array}{c}\mathrm{Co} \\
\mathbf{8}\end{array}$ & $\begin{array}{c}\mathrm{Cr} \\
200\end{array}$ & $\begin{array}{l}\mathrm{Cu} \\
\mathbf{7 0}\end{array}$ & $\mathrm{Fe}$ & $\mathrm{MgO}$ & $\mathrm{Mn}$ & $\begin{array}{c}\mathrm{Ni} \\
100\end{array}$ & $\begin{array}{l}\mathrm{Pb} \\
16\end{array}$ \\
\hline & 2460 & 105300 & 43.28 & 150000 & 87.00 & 14.94 & 1.52 & $2,600.00$ & 174.00 & 148.00 \\
\hline & & & 2 & & & & & & 2.00 & 5.00 \\
\hline & 17 & 211 & 4. & 89. & 12.6 & 3.2 & & 203.84 & 10.97 & 7.43 \\
\hline Iedian & 14.00 & 208.50 & 3.9 & 81.00 & 11.00 & 2.90 & 0.18 & 159.00 & 9.00 & 6.00 \\
\hline & 15 & 104.78 & 2.75 & 55.03 & 8.18 & 1.70 & 0.10 & 152.84 & 8.62 & 4.93 \\
\hline Skewn & 5.09 & 0.6 & 3.53 & 12.68 & 2.94 & 1.57 & 2.92 & 5.96 & 4.68 & 10.82 \\
\hline Kurtosis & 48.72 & 2.69 & 33.02 & 288.12 & 15.47 & 4.80 & 22.16 & 62.40 & 57.02 & 250.07 \\
\hline
\end{tabular}


of natural elements to health (Selinus et al., 2005; Flanagan et al., 2012; Lovell et al., 2014; Arhin et al., 2015). This review reiterates the findings of the previous studies that have attributed elements in geological materials (e.g. rocks, soils and groundwater) as causative factors of some noncommunicable diseases (Gomes and Silva, 2007; Selinus et al., 2005; Buck et al., 2016).

Anticipated medical geology issues

\section{Medical geology and sustainable development goals attainment in Ghana}

Though SDG 3 aspires to ensure health and well-being for all, this goal is essentially impractical following poor access to healthcare in rural areas within developing countries. Even in healthcare centers in urban areas, access to treatment for most diseases comes at a cost. Additionally, Ghana is relatively impoverished as compared with other developing counties, posing serious challenges to healthcare delivery. Though there is a continuous decline in poverty, the inequalities have not been ascertained (Macrotrends, 2020). In addition to the national poverty trends that are high, the achievement of universal health for all appears to be impractical due to the low level of hospitals, health centers in the country (Drislane et al., 2014). Based on these, the Government of Ghana implemented the National Health Insurance Scheme (NHIS) to increase access to health-care services and reduces financial barriers to health-care (Kipo-Sunyehzi et al., 2019).

However, it has been realized that there is a need to redesign the policy, to move it from current voluntary contributions, to adopt a broad tax-based approach to cover all citizens and persons with legal residence in Ghana (Kipo-Sunyehz et al., 2019). Also, a flexible premium payment system (specifically "payments by the installation" or "part payments") needs to be adopted. Due to the significantly high poverty levels, it is required to widen the scope of exempted groups in the NHIS to enroll more persons into the scheme. The real statistics of Ghana's healthcare as indicated by the UK Home Office report for Ghana states that:

Health-care expenditure is approximately USD100 per capita annually or about $6.2 \%$ of gross domestic product, both below the regional average. . .There are only 1.1 doctors and 9.8 nurses and midwives for every 10,000 inhabitants of Ghana, both of these are below even the low regional average and represent a real strain on the delivery of health-care.

Wide inequities exist in the delivery of health-care in Ghana, as only $24 \%$ of births from the lowest income quintile are attended by a skilled health professional, leading to much higher infant mortality rates.

Government spending makes up about half of the total health expenditure in Ghana, with about one-third of government spending in the form of a recently introduced social security system (Asemota, 2019).

Based on these insights presented on the NHIS coupled with the need to promote human well-being and to reduce the financial burden of Ghanaian citizens on healthcare, the Government of Ghana (particularly the Ministry of Health), should consider making medical geology an integral part of the public health agenda toward the attainment of SDG 3. Globally, elements in soils developed from underlying rocks play an integral role in the health of the exposed people. As increasing population and resource constraints increase, food production and food security have become a global issue. There is the need to recognize the importance of understanding the levels of essential and potentially harmful elements in the environment. This also helps to study disease patterns of elements that are related to elements that are accessible in the environments. The attainment of the SDG 3 (i.e. Good health and well-being) requires the knowledge of elements distributions and concentrations, which has not been investigated to outline geospatially, the hotspots of diseasecausing elements-zone in Ghana is a necessity. This renders the essentiality of medical geology 


\section{EFCC} 2,4

Table 2.

Summary statistics of $\operatorname{arsenic}(\mathrm{As})$ for the study area (unit measurements in $\mathrm{mg} / \mathrm{kg})$ research crucial for Ghana's achievement of SDG 3 goal for healthy lives and promotion of wellbeing for all its citizenry.

\section{Methods}

The study entailed a review of relevant literature on earth and health, as well as the empirical studies relating to medical geological issues in Ghana. For the known medical geology issues in Ghana, keywords such as medical geology and health, the link between medicine and health and further relate these search phrases to identify Ghanaian situations were searched in Google and Google Scholar, Microsoft Academic, BASE, Baidu Scholar, CORE, Semantic Scholar and Science.gov. The search showed that though several studies had been done on environmental health and soil chemistry in mining areas in Ghana, the majority of these studies did not consider the empirical data on health emanating from disease-causing elements. This study, therefore, focused majorly on As, as it has an association with gold in the Birimian system of Ghana and a major element that has contributed to debilitating health implications in some major mining communities in Ghana. As gold has an association with certain rocks and minerals, it was anticipated to connect directly to geology and health. Also, a geospatial map of As using the As results were created. This was done to assess the media reportage by the medical doctors' suspicion of renal diseases in most parts of the Western and Central Regions suspected to have relationships with the operations of mining activities (JoyNews, 2017).

Furthermore, the review relies on data that reappraises data published in Arhin et al. (2019) to highlights the close connection between medical geology and health. In total 2,868 soil samples collected from Akropong, Asankrangwa, Samreboi and Bogoso and the surrounding areas of the four traditional capitals in the Western Region were used. Out of the 51 elements analyzed per sample, it was only As that was evaluated for its pollution status relative to human health implications. A baseline value of $10 \mathrm{mg} / \mathrm{kg}$ was used to assess the deficiency or excesses in the samples. The quality of the analytical data from the ALS Geochemical laboratory based on Arhin et al. (2019) data was rechecked as part of the $\mathrm{QA} / \mathrm{QC}$ analysis to monitor the analytical quality. Results of the three reference materials (SARM 1, SARM 2 and AMIS 17) inserted in the batch of samples sent to the laboratory were re-plotted and evaluated for accuracy and precision.

\section{Results and discussions}

From Table 2, a maximum of $246 \mathrm{mg} / \mathrm{kg}$ and a minimum of $2 \mathrm{mg} / \mathrm{kg}$ of As were recorded in the samples. The mean As measured for the entire study area from 2,868 samples analyzed was $17.36 \mathrm{mg} / \mathrm{kg}$. This average value was $73.6 \%$ higher than the accepted baseline value of $10 \mathrm{mg} / \mathrm{kg}$. The median measured from the recorded assays for As was $14 \mathrm{mg} / \mathrm{kg}$. This implies that 2014 samples registered As assay values greater than $10 \mathrm{mg} / \mathrm{kg}$. This translates

\begin{tabular}{lr}
\hline & \multicolumn{1}{c}{ As } \\
\hline Maximum & 246.00 \\
Minimum & 2.00 \\
Mean & 17.36 \\
Median & 14.00 \\
Standard deviation & 15.54 \\
Skewness & 5.09 \\
Kurtosis & 48.72 \\
\hline
\end{tabular}


to about $70.2 \%$ of the total samples analyzed. Also, the low standard deviation $(15.54 \mathrm{mg} / \mathrm{kg})$ suggests a looseness of the As values.

Most of the areas enriched in As suggest its dominance probably in the underlying rocks. The spread and the uneven concentrations of As in the area are an indication of the effects of different soil formation processes and the varying environmental activities. As is known as one of the most abundant contaminants in water and soil and many epidemiological studies have found an association between As and type 2 diabetes mellitus, hypertension and cancer (Mandal and Suzuki, 2002; Shankar and Shanker, 2014; WHO, 2018). The presence of As-rich

Anticipated medical geology issues soils above-accepted baseline values could accumulate in food crops produced within the area may 3contribute to As-related-diseases.

Similarly, the plot of As shown in Figure 2 portrayed most of the area investigated to be at risk of As-related-diseases. The map suggests more than half of the area studied have As levels higher than $10 \mathrm{mg} / \mathrm{kg}$ (i.e. the global baseline value in soils). As, an element in arsenopyrite has traditionally been considered chemically unstable in the surficial environment (Craw and Pacheco, 2002; Basu and Schreiber, 2013). Its oxidation from the reduced environment to the oxidizing environment of arsenopyrite allows the widespread mechanism for the distribution of As into the environment (Craw and Pacheco, 2002; Craw et al., 2003). Presented in Figure 2, the southeastern and North-western parts of the study areas have the highest concentrations of As. These areas are known for artisanal and largescale mining activities with poor enforcement of mining regulations. The reappraisal of the As data in this study supports the idea of the relationship between medical geology and

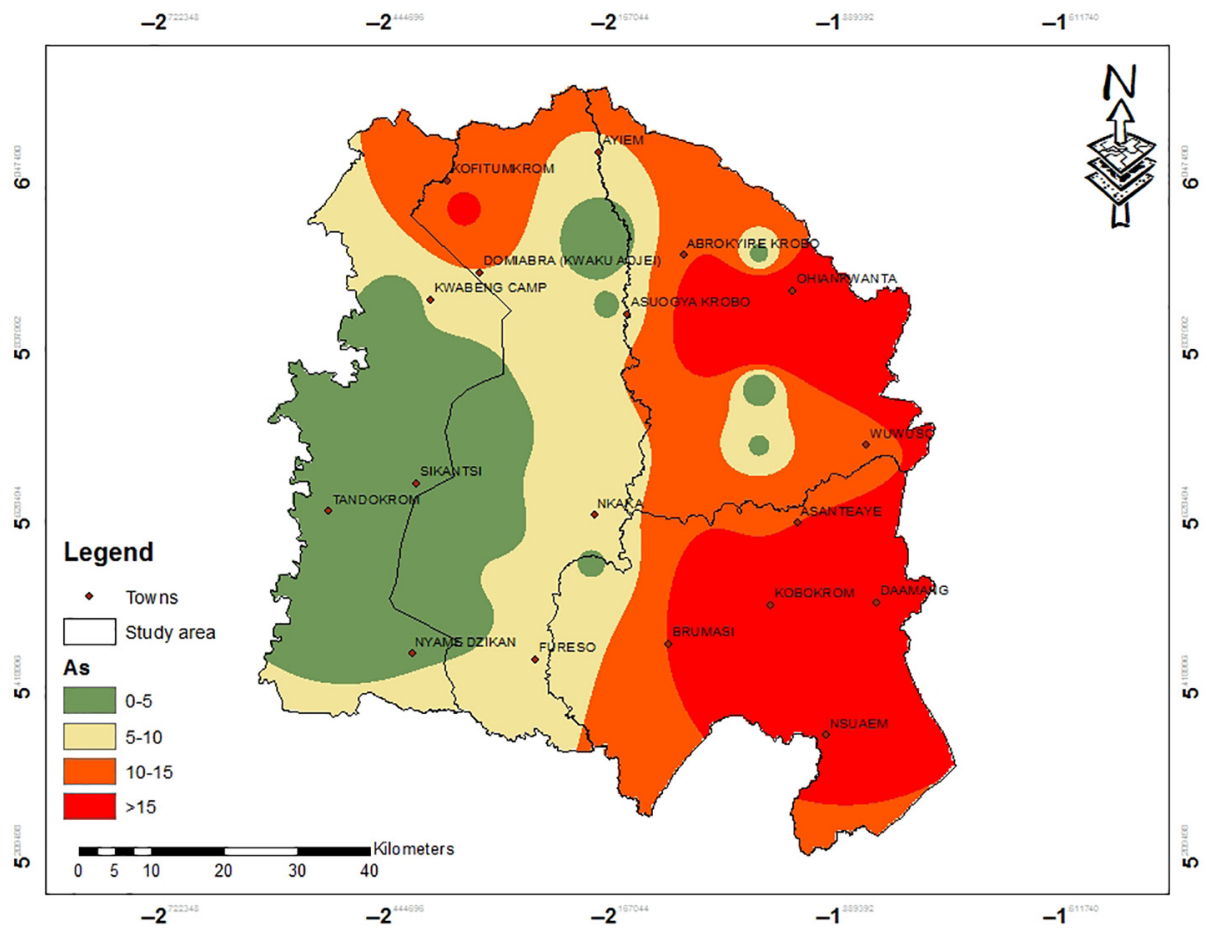

Figure 2. Distribution of Arsenic concentration in the study area 
EFCC 2,4 health as As exposure beyond threshold levels contributes to cardiovascular diseases including hypertension and diabetes in the areas.

Though, there are published reports of As in groundwater in Ghana, diseases related to As exposures have not been investigated in detail to understand the associated dangers of exposers. This element is naturally occurring and its colorless, tasteless and odorless nature makes it difficult to be observed visually in drinking water (boreholes and wells) (Islam, 2004; Kuivenhoven and Mason, 2019). Therefore, the consumption of contaminated water is unnoticed. The observance of As in water in Tarkwa and Obuasi (mining areas in Ghana) by Asante et al. (2007) and Bempah et al. (2013), respectively, and other parts of Africa by Ahoulé et al. (2015) suggest the possible occurrence, contribution to diseases and death through As exposure in these mining areas. Though the presence of As in Ghanaian soils is known, there is insufficient health data to establish this relationship. Relating Astoxicity to hypertension, cardiovascular disease, cancer, stroke (cerebrovascular diseases), chronic lower respiratory diseases and diabetes recognized by the Ghana Health Service which are among the major killer-diseases may have their sources to As.

Other known medical geology-related health issues have been reported in different forms in Ghana. For instance, Foli et al. (2011) report As and Hg in groundwater and surface water bodies in and around the Obuasi area. Similarly, Serfor-Armah et al. (2006) observed above threshold concentrations of As and antimony in water and sediment from Prestea. Iodine an element in minerals and some rocks are deficient in soils in northern Ghana and has resulted in the enlargement of the thyroid gland to people exposed to deficient iodine (Smallridge, 2012), while the excessiveness and deficiencies of fluoride in soils and drinking water also cause fluorosis and caries (Arhin and Affam, 2010; Craig et al., 2010). Similarly, Obiri et al. (2016) recorded As, $\mathrm{Hg}, \mathrm{Cd}, \mathrm{Cu}, \mathrm{Pd}, \mathrm{Zn}$ and $\mathrm{Mn}$ in the serum and blood of adults in the Prestea-Huni Valley District and Tarkwa-Nsuaem Municipality in South-western Ghana.

Also, the consumption of geophagic materials whose health impacts have not been completely known is practiced countrywide (Abdul and Arhin, 2020). Other known medical geology-related diseases include dental caries and fluorosis caused by deficiencies and excesses of fluoride obtained in drinking water and food. The avoidance of these diseases requires drinking water maintained within a baseline value of $0.5 \mathrm{mg} / \mathrm{L}$ to $1.5 \mathrm{mg} / \mathrm{L}$ and worldwide acceptable limits for fluoride in food crops. High values of fluoride have been detected in boreholes particularly in Northern Ghana to have links to biotite-granites within the area (Apambire, 2000; Yidana, 2012).

Several researchers have indicated that communities that rely on high fluoride groundwater as a source of drinking water are at high risk of dental fluorosis and skeletal fluorosis and have suggested that the WHO baseline values of $0.5 \mathrm{mg} / \mathrm{L}$ to $1.5 \mathrm{mg} /$ to have adhered to Apambire et al. (1997), Apambire, 2000; World Health Organization (WHO), 2011; Affam, 2012; Yidana, 2012).

Conversely, iodine is an essential element for humans and mammals and is useful in the thyroid gland (Arhin and Kazapoe, 2017). However, a deficiency in thyroid hormone thyroxin results in goiter (Kapil, 2007). This physical enlargement of the thyroid gland is very common in some parts of Ghana (Dei-Tutu et al., 2013). This relates to the underlying rocks and minerals (Pelig-Ba, 2008). Furthermore, as noted by Goldschmidt most iodine is derived from the volatilization of oceans which are subsequently transported onto the land (Goldschmidt, 1954). Also, others are associated with some rocks and chalcophile minerals (Fuge and Johnson, 1984). This may explain the prevalence of goiter in most parts of northern Ghana compared to other areas in Ghana (Abu et al., 2019). However, there is another aspect of intellectual or developmental disability (IDD) resulting from iodine deficiency which does not affect the physical appearance of the person but damages the 
brain. This is described as cretinism (Cao et al., 1994; Pharoah, 2020). There are not many discussions on this condition known as cretinism, a disease that causes stunted growth and general development alongside brain damage in Ghana (Amoah, 2019). This is less studied because it is not physically recognizable. A UNICEF (2018) report revealed that about 19 million newborn babies around the world to be at risk of permanent but preventable brain damage every year. The evidence of goiter in Ghana as indicated by Abu et al. (2019) suggests the possible occurrence of cretinism. This IDD should be considered as a major known medical geology issue and that the geographic locations ought to be mapped and defined for prevention and interventions.

Furthermore, in Ghana, almost all artisanal and small-scale mining companies use mercury during gold extraction (Foli et al., 2011; Obiri et al., 2016; Clifford, 2017). This process of gold extraction using inorganic mercury is described as amalgamation. The hazards of inorganic mercury poisoning have also been established dated back to the Roman times; the Mina Mata incidence where about 2,000 people died (Marsh, 1979). The health registration process in Ghana makes it very challenging to identify patients suffering from $\mathrm{Hg}$ exposure. However, inference from the Mina Mata incidence showed that methylated from mercury could cause a blood-brain barrier, and therefore induce severe neuronal destruction in extremely small doses (Darkwah, 2017). The study further emphasized the increasing menace of mercury in Ghana as many more different diseases are affecting people due to mercury exposure (Darkwah, 2017).

Evidence of mercury poisoning has been identified in illegal mining sites affecting soil for food cultivation and drinking water in communities close to river bodies such as the Birim, Enu, Pra, Bonsa and Ankobra (Tschakert, 2010). However, following the large scale of mining in Ghana, there may be other water bodies that have been badly polluted by mercury but have not been determined. Apart from mining processes, mercury is also released in cement production, waste incineration and other mercury-added products in the market. These are eventually transported into fishes that are consumed (Aikins, 2007). Again, mercury may find its way into human physiological functions through inhalation and ingestion and will consequently impact the public health system (Bernhoft, 2012; WHO, 2017a, 2017b).

This review, supported by the empirical data evaluated in this study suggests that there are non-communicable diseases that were not originally linked to a large variety of people but now appear to be endemic (Remais et al., 2013). These diseases tend to have an association with elements considered to be essential to human development. These elements $\mathrm{Fe}, \mathrm{Mg}$, manganese (Mn), Se, I, Cr, Cu, Zn, molybdenum (Mo), tungsten (W), phosphorus (P) and potassium $(\mathrm{K})$ play an important role in the physiological functions of human development. The proper functionality of the human body requires some amount of these essential elements. The dose-uptake of these elements determines the response of the body and this requires monitoring. These elements collectively have five general physiological roles. These are:

(1) Bone and membrane structure,

(2) Water and electrolyte balance,

(3) Metabolic catalysis,

(4) Oxygen binding and transport; and

(5) Hormone effects.

Non-essential elements including $\mathrm{Pb}, \mathrm{Ni}, \mathrm{Al}$ and $\mathrm{Cd}$ are tolerable at low levels on assimilation but become toxic and even lethal at increase assimilations (Stankovic and 
EFCC

2,4

Stankovic, 2013; Stankovic et al., 2014). Li et al. (2016) and Kumar and Hemantaranjan (2017), respectively, mentioned that though $\mathrm{Fe}$ and I are essential elements, toxic uptakes may pose ominous health consequences. It has been noted that acute iodine toxicity is rare but if uncontrolled can results in burning of the mouth, throat and stomach, produce fever, nausea, vomiting, diarrhea, a weak pulse, cyanosis and sometimes coma. Similarly, Fe-overload can have an extremely corrosive effect on the gastrointestinal (GI) mucosa, which can manifest as nausea, vomiting, abdominal pain, hematemesis and diarrhea (Southern and Jwayyed, 2020). Patients with toxic ingestion of Fe may become hypovolemic because of significant fluid and blood loss (Cheney et al., 1995). Some cardiovascular diseases such as cardiomyopathy, atherosclerosis and hypertension are also associated with toxicities of $\mathrm{Se}, \mathrm{Co}, \mathrm{Hg}, \mathrm{Fe}$ and $\mathrm{Pb}$ (Yang et al., 2020). Also, Swaminathan (2003) indicated that Mg deficiency can cause a wide variety of features including hypocalcemia, hypokalaemia and cardiac and neurological manifestations whereas chronic low Mg concentrations may result in diabetes, hypertension, coronary heart diseases and osteoporosis. With the five geological provinces (Figure 2) in Ghana, a miscellany of elements distributions and concentrations will be obtained for soil samples collected across the Ghanaian landscape.

Disease patterns will be dictated by the combined sources of the PTEs and the essential elements. The combined sources of elements may impact public health. For instance, a recent WHO report indicates NCDs such as heart disease, cancer, diabetes and lung diseases represent the largest causes of death in people aged less than 70 years globally (Bosu, 2012). Smith (2000) discussed that the health implications associated with disease-causing elements develop slowly and may cause health complications including skin lesions, skin cancer and some internal cancers affecting the kidney, bladder and lungs disorders, neurological effects, cardiovascular and hypertension, pulmonary and peripheral vascular diseases and diabetes mellitus.

It is, therefore, anticipated that continuous implications posed by mining activities could result in:

- Negative impacts of gaseous pollutants that received little attention such as $\mathrm{SO}_{2}$ and $\mathrm{NO}_{\mathrm{x}}$ with mining areas are anticipated due to drilling, excavation and tripping activities during mining. $\mathrm{SO}_{2}$ and $\mathrm{NO}_{\mathrm{x}}$ are likely to contribute to respiratory system disorders, cough, asthma, irritation of eyes and chronic bronchitis.

- Duncan (2020) stated that high levels of suspended solids resulting from mining activities have contributed to the high cost of treating water which has led to the closure of some water treatment plants in Ghana. These reported implications and continuous contamination of water bodies in mining areas could result in high pollution levels beyond treatment for human use.

- Gray (1997) and Singovszka et al. (2017) have revealed deleterious impacts of acid drainage on aquatic life when acidic waters are discharged into nearby streams and surface waters. This indicates that pollution of water bodies within mining areas could destroy aquatic habitats and aquatic lives through acid drainage.

- Continuous-unregulated mining renders agricultural land infertile. This could gradually lead to food insecurity in such areas. Also, crops that are native to such areas may be lost.

- Ghana is endowed with medicinal plants, especially in its forested areas (Witol, 2010). However, these medicinal resources could be lost through the continuous loss of forest resources. 
- The identification of above-threshold concentrations of heavy metals in some mining areas in Ghana by Apambire et al. (1997), Yidana (2012), Obiri et al. (2016) and Arhin et al. (2019) suggest that toxic elements resulting from mining activities may bio-accumulate in crops and this could pose deleterious public health implications on consumers.

- Increasing sediment loads can smother benthic organisms in streams and rivers, eliminating important food sources for predators and decrease available habitats for fishes to migrate and spawn (Johnson, 1998). This could reduce fish productivity in water bodies that have been threatened by unregulated and unmonitored mining activities.

- Erosion from waste rock piles or runoff after heavy rainfall often increases the sediment load of nearby water bodies (Johnson, 1997). Mining inside and along water bodies and the disposal of mine waste and piles that contain toxic chemicals could render water bodies to lose their aesthetics value or dry up through siltation. This results from high turbidity which reduces available light reaching aquatic plants for photosynthesis.

- Potential conflicts between mining and other land use and continuous negative implications on the environment and public health may prompt communities, government and regulatory bodies to pass non-binding referendums to reduce or ban mineral development.

\section{Conclusion}

The rocks in Ghana release PHEs and essential elements during weathering. These elements reside in the surface soils where food and drinking water are obtained. The concentrations of these elements vary across the landscape and in certain areas the levels are influenced by local activities. The uptakes of the toxic and essential elements based on the baseline values of the specific elements could influence the health of inhabitants. The health impacts at a place could be huge as the pathways of the source elements to the receptors (humans, animals and plants including food) may be the same. The accidental consumption of food or water from contaminated terrain may affect millions of people as did in Bangladesh and West Bengal. The study found the sporadic concentration levels of the known elementscausing diseases to have resulted in widespread uncontrolled diseases. Typical of them are goiter (IDD) and fluorosis and dental caries (excesses and deficiencies of $\mathrm{F}^{-}$). These diseases present physically evident. Known and anticipated medical geology issues in Ghana can be averted through mapping and outlining hotspots and cold-spots of disease-related-elements. These maps can guide in devising mitigation and prevention strategies against the impacts on the environment on Public Health. The authors recommend interdisciplinary research in medical geology and public health as that will create a pathway toward addressing the internationally-agreed goal of health for all.

\section{References}

Abdul, R.M. and Arhin, E. (2020), "Mineralogy and geochemistry of geophagic soils in Ghana: a review", European Journal of Environment and Earth Sciences, Vol. 1 No. 3.

Abu, B.A., Oldewage-Theron, W. and Aryeetey, R.N. (2019), "Risks of excess iodine intake in Ghana: current situation, challenges, and lessons for the future", Annals of the New York Academy of Sciences, Vol. 1446 No. 1, p. 117. 
EFCC 2,4

Affam, M., Arhin, E. and Asamoah, D.N. (2012), "Sources of endemic fluorosis attributed to igneous granitoid in Northern Ghana", Paper presented at: 2nd Umat Biennial International Mining and Mineral Conference, Tarkwa, Ghana.

Ahoulé, D.G., Lalanne, F., Mendret, J., Brosillon, S. and Maïga, A.H. (2015), “Arsenic in African waters: a review", Water, Air, and Soil Pollution, Vol. 226 No. 9, pp. 1-13.

Aikins, A.D. (2007), "Ghana's neglected chronic disease epidemic: a developmental challenge”, Ghana Medical Journal, Vol. 41 No. 4, p. 154.

Amoah, J.A. (2019), "Appraisal of malnutrition on academic performance of students in the basic schools in Ghana", American Journal of Food Science and Health, Vol. 5 No. 2, pp. 38-45.

Apambire, W.B. (2000), "Geochemical modeling and geomedical implications of fluoriferous groundwaters in the Upper East region of Ghana", Ph.D. dissertation, NV-Reno (USA), p. 123, available at: www.elibrary.ru.

Apambire, W.B., Boyle, D.R. and Michel, F.A. (1997), "Geochemistry, genesis, and health implications of fluoriferous groundwaters in the upper regions of Ghana”, Environmental Geology, Vol. 33 No. 1, pp. 13-24.

Arhin, E. and Affam, M. (2010), "Fluoride in groundwater and its implications in west Gonja dstrict of Ghana”, Ghana Mining Journal, p. 11.

Arhin, E. and Kazapoe, R. (2017), "Selenium in locally produced food crops and implications on healthy eating: a case study at the talensi district of Ghana".

Arhin, E., Jenkin, G.R., Cunningham, D. and Nude, P. (2015), "Regolith mapping of deeply weathered terrain in savannah regions of the Birimian lawra greenstone belt, Ghana", Journal of Geochemical Exploration, Vol. 159, pp. 194-207.

Arhin, E., Kazapoe, R.W. and Salami, F. (2020), "Linking geology to the prevalence of noncommunicable diseases: a case study of the voltaian sedimentary basin, Ghana”, Ecofeminism and Climate Change., Vol. 2 No. 1.

Arhin, E., Zhang, C. and Kazapoe, R. (2019), "Medical geological study of disease-causing elements in Wassa area of southwest Ghana", Environmental Geochemistry and Health, Vol. 41 No. 6, pp. 2859-2874.

Asante, K.A., Agusa, T., Subramanian, A., Ansa-Asare, O.D., Biney, C.A. and Tanabe, S. (2007), "Contamination status of arsenic and other trace elements in drinking water and residents from tarkwa, a historic mining township in Ghana”, Chemosphere, Vol. 66 No. 8, pp. 1513-1522.

Asemota, E. (2019), “Cornell policy review: better care, better health: optimizing healthcare provision in Ghana”, 25 January 2019, available at: www.cornellpolicyreview.com/healthcare-in-ghana (accessed January 21).

Basu, A. and Schreiber, M.E. (2013), "Arsenic release from arsenopyrite weathering: insights from sequential extraction and microscopic studies”, Journal of Hazardous Materials, Vol. 262, pp. 896-904.

Bempah, C.K., Ewusi, A., Obiri-Yeboah, S., Asabere, S.B., Mensah, F., Boateng, J. and Voigt, H.J. (2013), "Distribution of arsenic and heavy metals from mine tailings dams at obuasi municipality of Ghana", Research Journal of Environmental and Earth Sciences, Vol. 5 No. 1, pp. 61-70.

Bernhoft, R.A. (2012), "Mercury toxicity and treatment: a review of the literature", Journal of Environmental and Public Health, Vol. 2012.

Bosu, W.K. (2012), "A comprehensive review of the policy and programmatic response to chronic noncommunicable disease in Ghana", Ghana Medical Journal, Vol. 46 No. 2 Suppl, pp. 69-78.

Buck, B.J., Londono, S.C., McLaurin, B.T., Metcalf, R., Mouri, H., Selinus, O. and Shelembe, R. (2016), "The emerging field of medical geology in brief: some examples", Environmental Earth Sciences, Vol. 75 No. 6, p. 449.

Cao, X.Y., Jiang, X.M., Dou, Z.H., Rakeman, M.A., Zhang, M.L., O’Donnell, K., .. DeLong, G.R. (1994), "Timing of vulnerability of the brain to iodine deficiency in endemic cretinism", New England Journal of Medicine, Vol. 331 No. 26, pp. 1739-1744. 
Chen, A.M. (2020), "Atherosclerosis. U.S. National library of medicine", available from: https:// medlineplus.gov/ency/article/000171.htm (accessed 17 January 2021).

Chen, M., Ma, L.Q. and Harris, W.G. (1999), "Baseline concentrations of 15 trace elements in Florida surface soils", Journal of Environmental Quality, Vol. 28 No. 4, pp. 1173-1181.

Cheney, K., Gumbiner, C., Benson, B. and Tenenbein, M. (1995), "Survival after a severe iron poisoning treated with intermittent infusions of deferoxamine", Journal of Toxicology: Clinical Toxicology, Vol. 33 No. 1, pp. 61-66.

Clifford, M.J. (2017), "Assessing releases of mercury from small-scale gold mining sites in Ghana”, The Extractive Industries and Society, Vol. 4 No. 3, pp. 497-505.

Craig, L., Thomas, J.M., Lutz, A. and Decker, D.L. (2018), "Determining the optimum locations for pumping low-fluoride groundwater to distribute to communities in a fluoridic area in the Upper East Region, Ghana", Chem Geol, Vol. 476, pp. 481-492.

Craw, D. and Pacheco, L. (2002), "Mobilisation and bioavailability of arsenic around mesothermal gold deposits in a semiarid environment, Otago, New Zealand", The Scientific World Journal, Vol. 2, pp. 308-319.

Craw, D., Falconer, D. and Youngson, J.H. (2003), "Environmental arsenopyrite stability and dissolution: theory, experiment, and field observations", Chemical Geology, Vol. 199 Nos 1/2, pp. 71-82.

Darkwah, J.A. (2017), “The creeping mercury menace - Solution is here! UNDP report 2017”, available at: www.gh.undp.org/content/ghana/en/home/ourperspective/ourperspectivearticles/2017/08/ 16/the-creeping-mercury-menace-solution-is-here-html (accessed 12 December 2020).

Dei-Tutu, S.A., Manful, A., Heimburger, D.C., Malechi, H., Moore, D.J., Oppong, S.A. ... and Aliyu, M.H. (2020), "Correlating maternal iodine status with neonatal thyroid function in two hospital populations in Ghana: a multicenter cross-sectional pilot study", BMC pediatrics, Vol. 20 No. 1, p. 26.

De Miguel, E., Iribarren, I., Chacon, E., Ordonez, A. and Charlesworth, S. (2007), "Risk-based evaluation of the exposure of children to trace elements in playgrounds in Madrid (Spain)", Chemosphere, Vol. 66 No. 3, pp. 505-513.

Drislane, F.W., Akpalu, A. and Wegdam, H.H. (2014), "The medical system in Ghana”, The Yale Journal of Biology and Medicine, Vol. 87 No. 3, p. 321.

Duncan, A.E. (2020), "The dangerous couple: illegal mining and water pollution - a case study in fena river in the Ashanti region of Ghana", Journal of Chemistry, Vol. 2020.

Dzigbodi-Adjimah, K. (1993), "Geology and geochemical patterns of the birimian gold deposits, Ghana, West Africa”, Journal of Geochemical Exploration, Vol. 47 Nos 1/3, pp. 305-320.

England, P.C. and Richardson, S.W. (1977), "The influence of erosion upon the mineral fades of rocks from different metamorphic environments", Journal of the Geological Society, Vol. 134 No. 2, pp. 201-213.

Flanagan, S.V., Johnston, R.B. and Zheng, Y. (2012), "Arsenic in tube well water in Bangladesh: health and economic impacts and implications for arsenic mitigation", Bulletin of the World Health Organization, Vol. 90 No. 11, pp. 839-846.

Foli, G., Apeah, O.B. and Amedjoe, C.G. (2011), "Pre-mining water quality prediction from nonweathered sulphide ores along the Ashanti metallogenic belt in Ghana using acid-base accounting procedure", American Journal of Scientific and Industrial Research, Vol. 2 No. 5, pp. 827-833.

Fuge, R. and Johnson, C.C. (1984), "Evidence for the chalcophile nature of iodine", Chemical Geology, Vol. 43 Nos 3/4, pp. 347-352.

Goldschmidt, V.M. (1954), “Geochemistry”, $L W W$, Vol. 78 No. 2, p. 156.

Gomes, C.D.S.F. and Silva, J.B.P. (2007), "Minerals and clay minerals in medical geology”, Applied Clay Science, Vol. 36 Nos 1/3, pp. 4-21. 
EFCC 2,4

Gray, N.F. (1997), "Environmental impact and remediation of acid mine drainage: a management problem”, Environmental Geology, Vol. 30 Nos 1/2, pp. 62-71.

Hunter, B.M., Gray, H.B. and Muller, A.M. (2016), "Earth-abundant heterogeneous water oxidation catalysts", Chemical Reviews, Vol. 116 No. 22, pp. 14120-14136.

Integris (2017) "There's more to heart disease than heart attacks", available at: https:/integrisok.com/resources/ on-your-health/2017/february/theres-more-to-heart-disease-than-heart-attacks (accessed 28 December 2020).

Islam, A.M. (2004), Membrane Distillation Process for Pure Water and Removal of Arsenic, Chalmers University of Technology, Gothenburg, Sweden.

Johnson, S.W. (1997), "Hydrologic effects", in Marcus, J.J. (Ed.), Mining Environmental Handbook, Imperial College Press, London.

Johnson, S.W., Drice, S. and Moles, D.A. (1998), "Effects of submarine mine tailings disposal on juvenile yellowfin sole (pleuronectes asper): a laboratory study", Marine Pollution Bulletin, Vol. 36 No. 4, pp. 278-287.

JoyNews (2017) "Galamsey linked to kidney failures; 65 cases reported in Tarkwa", available at: www. myjoyonline.com/news/2017/august-14th/galamsey-linked-to-kidney-failures-65-cases-reportedin-tarkwa.php (accessed 02 January 2021).

Kapil, U. (2007), "Health consequences of iodine deficiency", Sultan Qaboos University Medical Journal, Vol. 7 No. 3, p. 267.

Kaplan, N.M. (2016), "We are what we eat (and drink)", Journal of the American Society of Hypertension, Vol. 10 No. 6, p. 474.

Kesse, G.O. (1985), The Mineral and Rock Resources of Ghana, in Balkema, A.A. (Ed.), Rotterdam, Netherlands, p. 610.

Kipo-Sunyehzi, D.D., Attuquayefio, P.K. and Sunyehzi, J.K. (2019), "Street-level bureaucrats' coping strategies and how they affect public service delivery in Ghana".

Kuivenhoven, M. and Mason, K. (2019), “Arsenic (arsine) toxicity”, available at: www.ncbi.nlm.nih.gov/ books/NBK541125/ (accessed 23 January 2021).

Kumar, P. and Hemantaranjan, A. (2017), "Iodine: a unique element with special reference to soil-plantair system”, Advances in Plant Physiology, Vol. 17, p. 314.

Li, G., Kronzucker, H.J. and Shi, W. (2016), "Root developmental adaptation to Fe toxicity: mechanisms and management", Plant Signaling and Behavior, Vol. 11 No. 1, p. e1117722.

Lovell, R., Wheeler, B.W., Higgins, S.L., Irvine, K.N. and Depledge, M.H. (2014), “A systematic review of the health and well-being benefits of bio diverse environments", Journal of Toxicology and Environmental Health, Part B, Vol. 17 No. 1, pp. 1-20.

Macrotrends (2020), “Ghana poverty rate 1987-2021”, available at: www.macrotrends.net/countries/ GHA/ghana/poverty-rate (accessed 20 January 2021).

Mandal, B.K. and Suzuki, K.T. (2002), "Arsenic round the world: a review”, Talanta, Vol. 58 No. 1, pp. 201-235.

Marsh, D.G. (1979), "Organic mercury: methylmercury compounds”, Handbook of Clinical Neurology, Vol. 36, pp. 73-81.

National Research Council (1989), "Diet and health: implications for reducing chronic disease risk", available at: https://pubmed.ncbi.nlm.nih.gov/25032333/ (accessed 15 January 2021).

Nkinahamira, F., Suanon, F., Chi, Q., Li, Y., Feng, M., Huang, X., . . Sun, Q. (2019), “Occurrence, geochemical fractionation, and environmental risk assessment of major and trace elements in sewage sludge”, Journal of Environmental Management, Vol. 249, p. 109427.

Obiri, S., Yeboah, P.O., Osae, S. and Adu-Kumi, S. (2016), "Levels of arsenic, mercury, cadmium, copper, lead, zinc and manganese in serum and whole blood of resident adults from mining and nonmining communities in Ghana”, Environmental Science and Pollution Research, Vol. 23 No. 16, pp. 16589-16597. 
Pelig-Ba, K.A. (2008), "Iodine in drinking water in the Northern region of Ghana: its relationship to iodine deficiency disorders", Ghana Journal of Development Studies, Vol. 5 No. 1, pp. 109-125.

Pharoah, P.O. (2020), "The modern history of iodine and the near eradication of cretinism".

Anticipated medical geology issues

Remais, J.V., Zeng, G., Li, G., Tian, L. and Engelgau, M.M. (2013), "Convergence of non-communicable and infectious diseases in low-and Middle-income countries", International Journal of Epidemiology, Vol. 42 No. 1, pp. 221-227.

Selinus, O., Alloway, B., Centeno, J.A., Finkelman Rb, Fuge, R., Lindh, et al. (2005), Essentials of Medical Geology: impacts of the Natural Environment on Public Health, Elsevier academic press, New York, NY, p. 812.

Serfor-Armah, Y., Nyarko, B.J.B., Dampare, S.B. and Adomako, D. (2006), "Levels of arsenic and antimony in water and sediment from prestea, a gold mining town in Ghana and its environs", Water, Air, and Soil Pollution, Vol. 175 Nos 1/4, pp. 181-192.

Shankar, S. and Shanker, U. (2014), "Arsenic contamination of groundwater: a review of sources, prevalence, health risks, and strategies for mitigation", The Scientific World Journal, Vol. 2014.

Singh, A. and Spiccia, L. (2013), "Water oxidation catalysts based on abundant 1st row transition metals", Coordination Chemistry Reviews, Vol. 257 Nos 17/18, pp. 2607-2622.

Singh, P.K., Singh, V.K., Rajak, P.K., Singh, M.P. and Naik, A.S. (2016), "Distribution and geochemistry of selected trace elements in the lignites of cambay basin, Gujarat, Western India", Journal of the Geological Society of India, Vol. 88 No. 2, pp. 131-146.

Singovszka, E., Balintova, M., Demcak, S. and Pavlikova, P. (2017), "Metal pollution indices of bottom sediment and surface water affected by acid mine drainage", Metals, Vol. 7 No. 8, p. 284.

Smallridge, R.C., Ain, K.B., Asa, S.L., Bible, K.C., Brierley, J.D., et al. (2012), "American thyroid association guidelines for management of patients with anaplastic thyroid cancer", Thyroid, Vol. 22 No. 11, pp. 1104-1139.

Smith, A.H., Lingas, E.O. and Rahman, M. (2000), "Contamination of drinking-water by arsenic in Bangladesh: a public health emergency", Bulletin of the World Health Organization, Vol. 78 No. 9, pp. 1093-1103.

Southern, A.P. and Jwayyed, S. (2020), "Iodine toxicity”, available at: www.ncbi.nlm.nih.gov/books/ NBK560770/ (accessed 01 February 2021).

Stankovic, S. and Stankovic, A.R. (2013), "Bioindicators of toxic metals", Green Materials for Energy, Products and Depollution, Springer, Dordrecht, pp. 151-228.

Stankovic, S., Kalaba, P. and Stankovic, A.R. (2014), "Biota as toxic metal indicators", Environmental Chemistry Letters, Vol. 12 No. 1, pp. 63-84.

Swaminathan, R. (2003), "Magnesium metabolism and its disorders", The Clinical Biochemist. Reviews, Vol. 24 No. 2, p. 47.

Tack, F.M.G., Verloo, M.G., Vanmechelen, L. and Van Ranst, E. (1997), "Baseline concentration levels of trace elements as a function of clay and organic carbon contents in soils in Flanders (Belgium)", Science of the Total Environment, Vol. 201 No. 2, pp. 113-123.

Tschakert, P. (2010), "Mercury in fish: a critical examination of gold mining and human contamination in Ghana", International Journal of Environment and Pollution, Vol. 41 Nos 3/4, pp. 214-228.

UNICEF (2018), Statistical Tables, State of the World's Children, pp. 146-205.

WHO (2017a) "Cardiovascular diseases (CVDs). key facts", available at: www.who.int/news-room/factsheets/detail/cardiovascular-diseases-(cvds) (accessed 30 December 2020).

WHO (2017b), "Mercury and health. Key facts", available at: www.who.int/news-room/fact-sheets/ detail/mercury-and-health (accessed 25 January 2021). 
EFCC

2,4

184

WHO (2018), "Arsenic. Key facts”, available at: www.who.int/news-room/fact-sheets/detail/arsenic (accessed January 15, 2021).

Witol, D. (2010), "Medicinal plants: Uses and preservation to ensure their sustainability in the nadowli district of the Upper West region", Doctoral dissertation, Ghana.

Wong, C.S., Li, X. and Thornton, I. (2006), "Urban environmental geochemistry of trace metals", Environmental Pollution, Vol. 142 No. 1, pp. 1-16.

World Health Organization (WHO) (2011), "Guidelines for drinking-water quality", WHO Chronicle, Vol. 38 No. 4, pp. 104-108.

Yang, A.M., Lo, K., Zheng, T.Z., Yang, J.L., Bai, Y.N., Feng, Y.Q., .. . Liu, S.M. (2020), "Environmental heavy metals and cardiovascular diseases: status and future direction", Chronic Diseases and Translational Medicine., Vol. 6 No. 4.

Yidana, S.M., Ophori, D., Yakubo, B.B. and Samed, A.A. (2012), "A factor model to explain the hydrochemistry and causes of fluoride enrichment in groundwater from the Middle voltaian sedimentary aquifers in the Northern region", Ghana. ARPNJEng Appl Sci, Vol. 7 No. 1, pp. 50-68.

\section{Further reading}

Davies, T.C. (2010), "Medical geology in africa”, Medical Geology 2010, Springer, Dordrecht, pp. 199-219.

Leube, A., Hirdes, W., Mauer, R. and Kesse, G.O. (1990), "The early proterozoic birimian supergroup of Ghana and some aspects of its associated gold mineralization", Precambrian Research, Vol. 46 Nos 1/2, pp. 139-165.

United Kingdom Home Office (2019), "Country policy and information note Ghana: medical and healthcare issues", available at: https:/assets.publishing.service.gov.uk/government/uploads/system/uploads/ attachment_data/file/812958/Ghana_-_Medical_and_Healthcare_-_CPIN_-_v1.0_GOV.UK_.pdf (accessed 28 January 2021).

\section{Corresponding author}

Raymond Webrah Kazapoe can be contacted at: rkazapoe@yahoo.com

For instructions on how to order reprints of this article, please visit our website: 